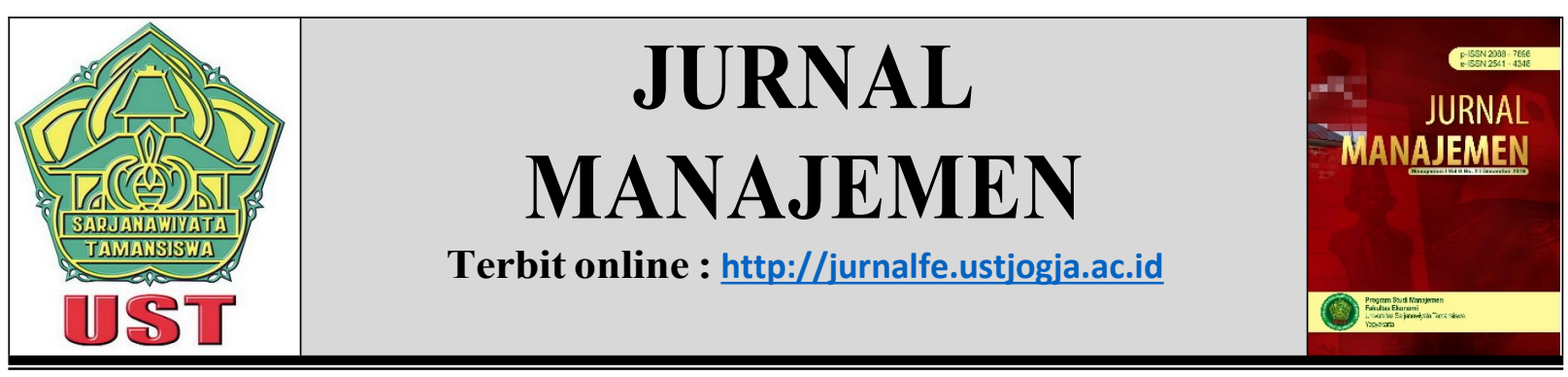

\title{
PENGARUH MUTASI DAN MOTIVASI KERJA TERHADAP KINERJA PEGAWAI (Berdasarkan Persepsi Responden pada Badan Pemeriksa Keuangan Republik Indonesia Perwakilan Provinsi Maluku Utara)
}

\author{
Dian Ratih Fikamissa Falegy ${ }^{1}$ \\ Aburrahman Kader ${ }^{2}$ \\ Sudirah $^{3}$
}

1,2,3 Program Pascasarjana Magister Administrasi Publik, Universitas Terbuka Email:dianratihfikamissafalegy@gmail.com

\begin{tabular}{|c|c|}
\hline Informasi Naskah & Abstrak \\
\hline $\begin{array}{l}\text { Diterima:6 April } 2021 \\
\text { Revisi: } 27 \text { Mei } 2021 \\
\text { Terbit: } 18 \text { Juni } 2021 \\
\end{array}$ & $\begin{array}{l}\text { This study was aimed to determine: employees' transfer; work } \\
\text { motivation; performance; the effect of employees transfer on the } \\
\text { performance; work motivation towards the performance; employees }\end{array}$ \\
\hline $\begin{array}{l}\text { Kata Kunci: employees } \\
\text { transfer, employees' } \\
\text { motivation, employees' } \\
\text { performance. }\end{array}$ & 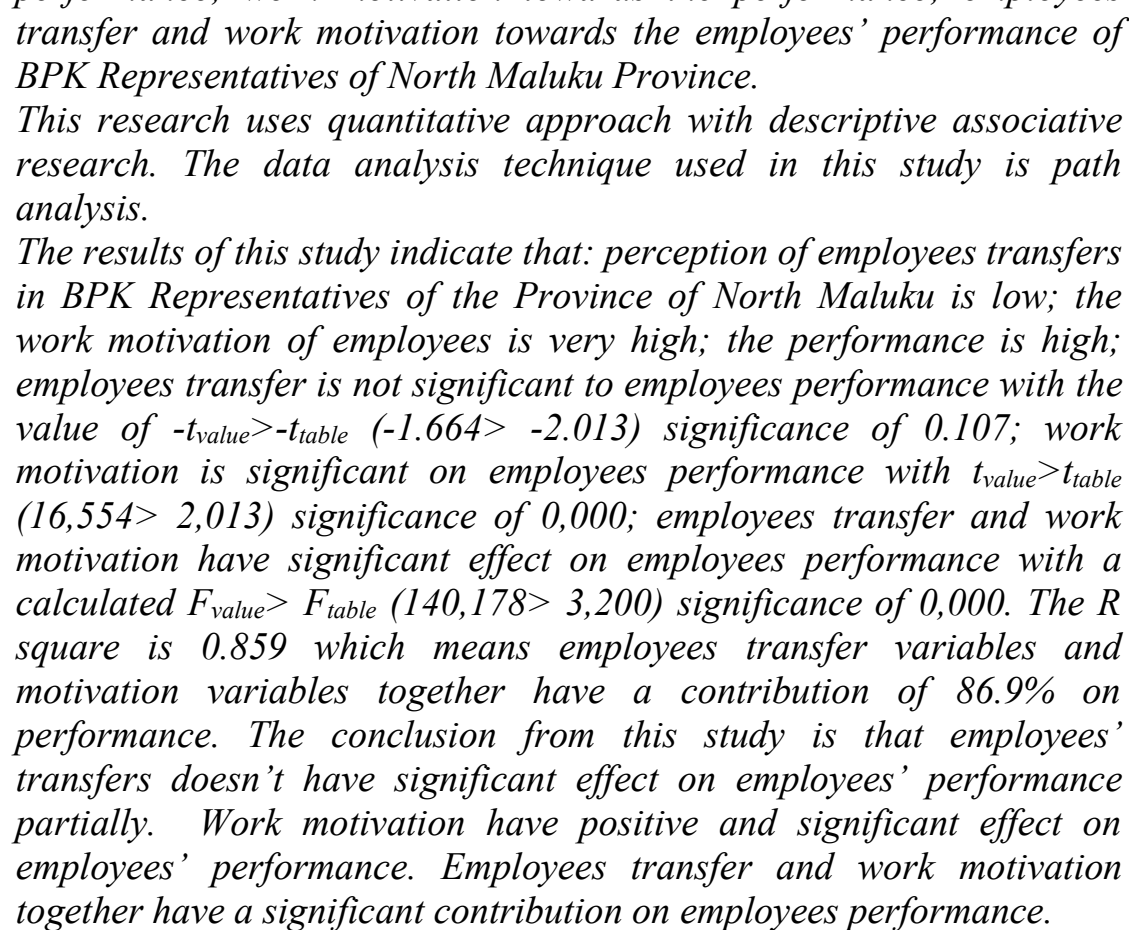 \\
\hline
\end{tabular}

\section{PENDAHULUAN}

Kinerja adalah hasil kerja atau kontribusi yang dicapai oleh individu dalam mencapai tujuan organisasi sesuai dengan tugas dan kewajibannya. Terdapat dua kriteria dalam mengukur kontribusi 
individu terhadap organisasi yaitu berdasarkan evaluasi hasil kerja dan berdasarkan evaluasi perilaku kerja, Gomes dalam Prasetya (2018). Berdasarkan evaluasi hasil kerja, diketahui bahwa selama tahun 2016 s.d. tahun 2018 Badan Pemeriksa Keuangan Perwakilan Provinsi Maluku Utara belum mampu mencapai keseluruhan indikator kinerja utama yang direncanakan dengan maksimal, yaitu belum tercapainya persentase penyelesaian tindak lanjut rekomendasi hasil pemeriksaan. Selain itu, hasil evaluasi perilaku kerja diketahui bahwa pegawai memiliki tingkat absensi yang cukup tinggi.

Salah satu faktor yang mempengaruhi kinerja pegawai adalah motivasi pegawai. Motivasi erat kaitannya dengan perilaku yang ditunjukkan pegawai dalam melaksanakan tugasnya sehari-hari. Motivasi merupakan pemberian daya untuk menggerakkan dan menciptakan antusiasme seorang karyawan sehingga mereka mau bekerja dan mau bekerja sama secara efektif dan terintegrasi sehingga diperoleh hasil yang memuaskan, Hasibuan (2016).

Faktor lain yang dapat mempengaruhi kinerja pegawai adalah mutasi pegawai. Menurut Siagian dalam Dewi (2017) Mutasi berfungsi untuk memberikan pengalaman baru, memperluas pengetahuan dan keterampilan karyawan, menghindari kejenuhan, untuk mengisi lowongan yang ada, dan meningkatkan motivasi karyawan. Sedangkan menurut Hasibuan (2016) tujuan pelaksanaan mutasi antara lain adalah: meningkatkan produktivitas, menempatkan orang-orang pada posisi yang tepat, meningkatkan pengetahuan pegawai, mendorong perencanaan karier, dan menciptakan keseimbangan struktur organisasi.

Mutasi pegawai memiliki manfaat yang sangat besar baik terhadap organisasi maupun terhadap pegawai itu sendiri. Di lingkungan Badan Pemeriksa Keuangan mutasi bagi pemeriksa sangat diperlukan untuk tetap menjaga independensi yang dimiliki oleh pegawai.

Di sisi lain, terdapat permasalahan psikologis yang harus dihadapi oleh pegawai terkait dengan pelaksanaan mutasi pegawai. Budiman (2018) menyatakan bahwa permasalah dalam mutasi pegawai dapat dibedakan ke dalam dua jenis yaitu permasalahan terkait pekerjaan dan permasalahan yang tidak terkait pekerjaan. Permasalahan terkait dengan pekerjaan seperti adaptasi terhadap lingkungan dan tanggung jawab yang baru. Sedangkan yang permasalahan yang tidak terkait dengan pekerjaan misalnya adalah keputusan mengenai keluarga, tempat tinggal baru, sosial dan emosional stress, dan sebagainya.

Permasalahan-permasalahan baik terkait dengan pekerjaan maupun tidak, jika tidak ditangani dengan baik dapat berpengaruh terhadap kinerja organisasi secara keseluruhan. Mignonac dalam Budiman (2018) menyatakan bahwa mutasi yang tidak diinginkan oleh pegawai dapat menyebabkan penurunan kinerja, resistensi, dan penurunan kualitas kerja. Secara singkat dapat terjadi perilaku penurunan kemampuan bekerja bahkan keinginan untuk berhenti bekerja.

Permasalahan mengenai mutasi pegawai di lingkungan pegawai BPK RI khususnya pada Perwakilan Provinsi Maluku Utara merupakan permasalahan yang sering dibahas oleh pegawai. Hal ini disebabkan karena sebagian besar pegawai BPK Maluku Utara adalah pegawai perantau yang tinggal terpisah dengan keluarganya. Semua pegawai BPK Maluku Utara tentunya menginginkan untuk berkumpul dan tinggal dengan keluarga. Salah satu harapan bagi pegawai untuk dapat berkumpul dengan keluarga adalah adanya kepastian mengenai pola mutasi sehingga pegawai dapat menentukan rencana jangka pajang bagi keluarganya.

Salah satu parameter untuk menilai motivasi adalah melalui kedisiplinan pegawai yang ditunjukkan dengan absensinya. Pada Badan Pemeriksa Keuangan Perwakilan Provinsi Maluku Utara tingkat absensi pegawai sepanjang Tahun 2017 s.d. 2018 diketahui bahwa rata-rata tingkat absensi pegawai BPK Perwakilan Provinsi Maluku Utara adalah sebesar 7,14. Hasibuan (2016) menyatakan bahwa absensi adalah ketidakhadiran karyawan di dalam organisasi dengan alasan-alasan tertentu. Jika tingkat absensi pegawai dalam suatu organisasi telah mencapai di atas 5,7\% maka dianggap melampaui batas kewajaran sehingga perlu dijadikan perhatian oleh manajemen. 
Berdasarkan pengamatan secara lebih mendalam diketahui bahwa banyak pegawai yang tidak mematuhi peraturan yang ada. Beberapa pegawai masuk kantor dengan pakaian yang tidak sesuai dengan aturan berpakaian misalnya tidak memakai sepatu, tanda pengenal, maupun pakaian kerja yang layak sebagaimana dipersyaratkan dalam peraturan yang berlaku.

Selain itu banyak pula pegawai yang masuk kantor hanya untuk melakukan presensi elektronik, istirahat di luar jam istirahat, dan meninggalkan tempat kerja tanpa alasan yang jelas khususnya jika atasan dari pegawai tersebut sedang tidak berada di tempat. Rata-rata keterlambatan pegawai cukup tinggi yaitu 0,41 jam per bulan. Berdasarkan uraian di atas, perlu dilakukan penelitian lebih lanjut apakah hal ini merupakan indikator rendahnya motivasi dan kinerja pegawai pada BPK Perwakilan Provinsi Maluku Utara.

Kondisi motivasi dan mutasi pegawai pada akhirnya akan bermuara pada kinerja organisasi. Berdasarkan data Laporan Akuntabilitas Kinerja BPK Perwakilan Provinsi Maluku Utara diketahui bahwa terdapat salah satu indikator kinerja utama organisasi yang selalu tidak tercapai dari tahun ke tahun yaitu persentase penyelesaian tindak lanjut rekomendasi hasil pemeriksaan. Hal ini menunjukkan bahwa terdapat kesenjangan antara kondisi kinerja ideal yang diharapkan oleh organisasi dengan kondisi yang sebenarnya.

\section{KAJIAN PUSTAKA DAN HIPOTESIS Manajemen Sumber Daya Manusia}

Menurut Mondy, Wayne R., dalam Panggabean (2016) Manajemen Sumber Daya Manusia (MSDM) ialah pemanfaatan SDM/karyawan demi mencapai tujuan yang telah ditetapkan oleh organisasi. Selain itu, Nickson, Dennis dalam Panggabean (2016) menyatakan bahwa MSDM merupakan upaya yang dilakukan oleh organisasi untuk mengelola sumber daya manusia demi mencapai tujuan organisasi. Selanjutnya Daft, Richard L. dalam Panggabean (2016) mengemukakan bahwa MSDM adalah pelaksanaan fungsi-fungsi manajemen secara efektif dan efisien untuk mencapai tujuan organisasi.

\section{Mutasi Pegawai}

Menurut Hasibuan (2016) mutasi pegawai adalah salah satu tugas dari pengembangan pegawai yang dilaksanakan dengan memindahkan atau mengubah posisi pegawai baik secara vertikal maupun secara horizontal di dalam suatu organisasi. Santoso dalam Dewi (2017) menyatakan bahwa mutasi adalah pemindahan pegawai dari bagian yang kelebihan tenaga ke bagian yang memerlukan tenaga.

\section{Motivasi Kerja}

Hasibuan (2016) menyatakan bahwa motivasi adalah upaya pendorong untuk menggerakkan dan menciptakan semangat dan gairah pegawai untuk bersedia bekerja dan bekerja sama secara efektif dan sinergis sehingga memperoleh hasil yang maksimal. Selanjutnya Mangkunegara (2017) menyatakan bahwa motivasi terlihat dari sikap seseorang pada sebuah organisasi dalam menghadapi situasi kerja. Dari berbagai macam definisi yang telah disebutkan dapat diambil kesimpulan bahwa motivasi adalah daya dorong yang menyebabkan seorang pegawai untuk mengerahkan segala kemampuan untuk melaksanakan kewajiban dan tugas yang diberikan sehingga tujuan yang diinginkan dapat tercapai.

\section{Kinerja Pegawai}

Sutrisno (2016) menyatakan, kinerja merupakan hasil kerja dari seorang pegawai atau karyawan di dalam suatu organisasi yang dilaksanakan sesuai dengan kewajiban dan tanggung jawab yang dibebankan kepadanya untuk mencapai suatu tujuan tertentu. Menurut Mathis and Jackson dalam Putri (2016) kinerja adalah hal-hal yang dilakukan maupun tidak dilakukan oleh seorang pegawai 
dalam melaksanakan pekerjaannya. Menurut Samsudin dalam Putri (2016) kinerja yaitu output atau hasil kerja pegawai baik secara kelompok maupun secara individu dalam suatu organisasi. Berdasarkan berbagai definisi yang ada, dapat disimpulkan bahwa kinerja merupakan hasil kerja yang dicapai oleh seorang pegawai sesuai dengan tugas dan kewajibannya untuk mencapai tujuan organisasi.

\section{Pengembangan Hipotesis}

Hasil penelitian yang dilakukan oleh Putri (2016) menyatakan bahwa terdapat hubungan yang sangat kuat antara mutasi karyawan dan kinerja karyawan operasional di Vio Cihampelas Bandung Hotel. Hasil penelitian Wutsqo (2017) juga menunjukkan hasil yang sama. Hasil dari penelitian tersebut salah satunya adalah bahwa mutasi pegawai berpengaruh secara positif dan signifikan terhadap kinerja pegawai.

\section{$H_{1}=$ Mutasi pegawai $\left(X_{1}\right)$ berpengaruh signifikan terhadap kinerja pegawai ( $Y$ )}

Hasil penelitian Dewi (2017) yang menyatakan bahwa terdapat pengaruh yang signifikan antara variabel motivasi dan variabel kinerja.

\section{$\mathrm{H}_{2}=$ Motivasi kerja $\left(\mathrm{X}_{2}\right)$ berpengaruh signifikan terhadap kinerja pegawai (Y)}

Hasil penelitian yang dilakukan oleh Dewi (2017). Berdasarkan penelitian tersebut diketahui bahwa terdapat pengaruh yang signifikan antara variabel mutasi dan variabel motivasi secara simultan terhadap variabel kinerja.

$H_{3}=$ Mutasi pegawai $\left(X_{1}\right)$ dan motivasi kerja $\left(X_{2}\right)$ secara simultan berpengaruh terhadap kinerja pegawai (Y).

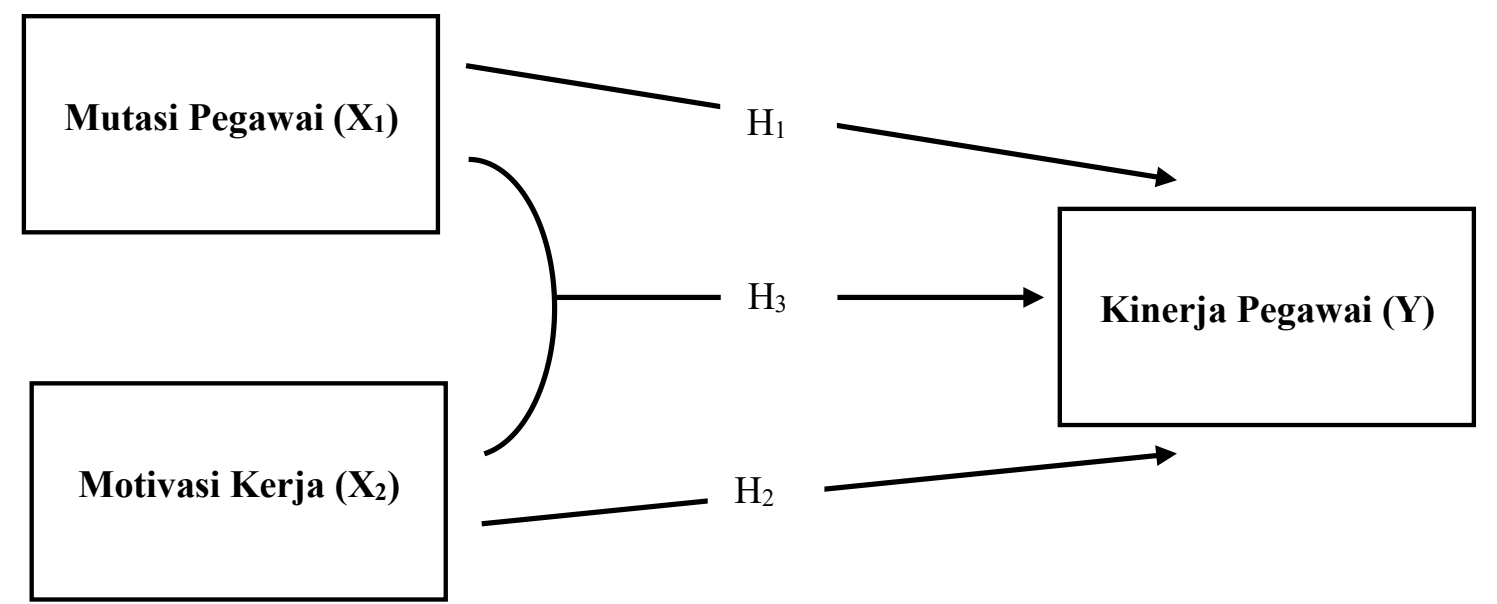

Gambar 1

Kerangka Teoritik Penelitian

\section{METODE PENELITIAN}

Penelitian ini menurut tingkat eksplanasinya bersifat deskriptif dan asosiatif. Sedangkan menurut jenis data dan analisis yang dilakukan penelitian ini menggunakan pendekatan penelitian kuantitatif. Prosedur pengumpulan data dilaksanakan melalui kuesioner sebagai sumber data utama, dan dilengkapi dengan wawancara/observasi dan analisis dokumen. Kuesioner penelitian digunakan untuk mengukur tingkat persepsi pegawai terhadap variabel mutasi pegawai, variabel motivasi kerja, dan variabel kinerja pegawai. Pertanyaan-pertanyaan penelitian didefinisikan dan diturunkan dari dimensi-dimensi variabel berdasarkan teori-teori yang telah ada sebelumnya. Pertanyaan-pertanyaan dalam kuesioner penelitian diuji validitasnya dengan metode korelasi product moment atau disebut juga uji Pearson. Sedangkakan reabilitas instrumen penelitian diuji dengan menggunakan metode koefisien alpha (alpha cronbach). 
Sampel penelitian adalah 49 orang Pegawai Negeri Sipil di Lingkungan BPK RI Perwakilan Provinsi Maluku Utara. Penyebaran kuesioner dilakukan dengan menggunakan e-form kepada seluruh populasi dengan data hasil kuesioner disajikan secara anonim dalam penelitian ini.

Teknik analisis data yang digunakan dalam penelitian ini adalah analisis jalur (path analysis). Metode analisis jalur dilengkapi dengan metode uji asumsi klasik guna memastikan bahwa data yang diperoleh tepat untuk dianalisis dengan menggunakan metode analisis jalur. Uji asumsi klasik yang dilakukan dalam penelitian ini adalah uji normalitas, uji multkolinearitas, uji heterokedastisitas, dan uji linearitas.

\section{HASIL DAN PEMBAHASAN}

Tabel 1

Karakteristik Responden Berdasarkan Umur, Jenis Kelamin, Tingkat Pendidikan, dan Status Pernikahan

\begin{tabular}{cccccccccccc}
\hline $\begin{array}{c}\text { Umur } \\
\text { (tahun) }\end{array}$ & $\mathrm{F}$ & $\%$ & $\begin{array}{c}\text { Jenis } \\
\text { Kelamin }\end{array}$ & $\mathrm{F}$ & $\%$ & $\begin{array}{c}\text { Tingkat } \\
\text { Pendidikan }\end{array}$ & $\mathrm{F}$ & $\%$ & $\begin{array}{c}\text { Status } \\
\text { Pernikahan }\end{array}$ & $\mathrm{F}$ & $\%$ \\
\hline $21-30$ & 34 & 70 & $\mathrm{~L}$ & 27 & 55 & $\mathrm{D} 3$ & 6 & 12 & $\mathrm{M}$ & 27 & 55 \\
\hline $31-40$ & 11 & 22 & $\mathrm{~F}$ & 22 & 45 & $\mathrm{~S} 1 / \mathrm{DIV}$ & 36 & 74 & $\mathrm{TM}$ & 22 & 45 \\
\hline $41-50$ & 4 & 8 & & & & $\mathrm{~S} 2$ & 7 & 14 & & & \\
\hline Total & 49 & & & 49 & & & 49 & & & 49 \\
\hline
\end{tabular}

Dari Tabel 1 diketahui bahwa Pegawai pada BPK Perwakilan Provinsi Maluku Utara didominasi oleh pegawai dengan usia produktif yaitu 70\% pegawai dengan usia antara 21-30 tahun dengan tingkat pendidikan yang memadai yaitu $74 \%$ dengan pendidikan S1.

Tabel 2

Data Statistik Deskriptif Penelitian (Rata-Rata Variabel)

\begin{tabular}{llrrrr}
\hline & N & Minimum & Maximum & Mean & Std. Deviation \\
\hline Mutasi $\left(\mathrm{X}_{1}\right)$ & 49 & 1,25 & 4,08 & 2,82 & 0,76 \\
\hline Motivasi Kerja $\left(\mathrm{X}_{2}\right)$ & 49 & 1,70 & 5,00 & 4,11 & 0,89 \\
\hline Kinerja (Y) & 49 & 1,00 & 5,00 & 3,87 & 0,86 \\
\hline Valid N (listwise) & 49 & & & & \\
\hline
\end{tabular}

Nilai rata-rata tiap variabel dibandingkan dengan rentang skala Neuman yang telah ditetapkan untuk menilai tingkat variabel adalah sebagai berikut: 4 - 5 sangat baik; 3 - 4 baik; 2 - 3 tidak baik; dan 1 - 2 sangat tidak baik. Dari tabel 1 diketahui bahwa, rata-rata jawaban responden untuk variabel mutasi $\left(\mathrm{X}_{1}\right)$ menunjukkan nilai rendah (nilai mean 2,82) yang menunjukkan bahwa persepsi mutasi yang dimiliki oleh pegawai pada BPK Perwakilan Provinsi Maluku Utara adalah rendah. Rata-rata jawaban responden untuk variabel motivasi kerja $\left(\mathrm{X}_{2}\right)$ menunjukkan nilai sangat baik (nilai mean 4,12) yang menunjukkan bahwa motivasi kerja pegawai pada Badan Pemeriksa Keuangan Perwakilan Provinsi Maluku Utara adalah sangat tinggi. Sedangkan Rata-rata jawaban responden menunjukkan nilai baik (nilai mean 3,87). Hal ini menunjukkan bahwa kinerja pegawai pada BPK Perwakilan Provinsi Maluku Utara adalah tinggi.

Tabel 3

Hasil Uji Validitas dan Reabilitas Instrumen Mutasi $\left(\mathrm{X}_{1}\right)$, Motivasi Kerja $\left(\mathrm{X}_{2}\right)$, dan Kinerja (Y) 


\begin{tabular}{ccccccccc}
\hline $\begin{array}{c}\text { Mutasi } \\
\text { Pegawai }\end{array}$ & $\begin{array}{c}\text { Nilai } \\
\mathrm{r}\end{array}$ & $\begin{array}{c}\text { Nilai } \\
\text { Cronbach's } \\
\text { Alpha }\end{array}$ & $\begin{array}{c}\text { Motovasi } \\
\text { Kerja }\end{array}$ & $\begin{array}{c}\text { Nilai } \\
\mathrm{r}\end{array}$ & $\begin{array}{c}\text { Nilai } \\
\text { Cronbach's } \\
\text { Alpha }\end{array}$ & $\begin{array}{c}\text { Kinerja } \\
\text { Pegawai }\end{array}$ & Nilai r & $\begin{array}{c}\text { Nilai } \\
\text { Cronbach's } \\
\text { Alpha }\end{array}$ \\
\hline $\mathrm{X}_{1,1}$ & 0,791 & 0,914 & $\mathrm{X}_{2,1}$ & 0,937 & 0,969 & $\mathrm{Y}_{1}$ & 0,912 & 0,970 \\
\hline $\mathrm{X}_{1,2}$ & 0,863 & 0,910 & $\mathrm{X}_{2,2}$ & 0,932 & 0,969 & $\mathrm{Y}_{2}$ & 0,943 & 0,969 \\
\hline $\mathrm{X}_{1,3}$ & 0,868 & 0,910 & $\mathrm{X}_{2,3}$ & 0,937 & 0,969 & $\mathrm{Y}_{3}$ & 0,894 & 0,971 \\
\hline $\mathrm{X}_{1,4}$ & 0,822 & 0,912 & $\mathrm{X}_{2,4}$ & 0,933 & 0,969 & $\mathrm{Y}_{4}$ & 0,963 & 0,969 \\
\hline $\mathrm{X}_{1,5}$ & 0,830 & 0,911 & $\mathrm{X}_{2,5}$ & 0,861 & 0,972 & $\mathrm{Y}_{5}$ & 0,894 & 0,971 \\
\hline $\mathrm{X}_{1,6}$ & 0,706 & 0,918 & $\mathrm{X}_{2,6}$ & 0,878 & 0,971 & $\mathrm{Y}_{6}$ & 0,842 & 0,973 \\
\hline $\mathrm{X}_{1,7}$ & 0,813 & 0,913 & $\mathrm{X}_{2,7}$ & 0,791 & 0,975 & $\mathrm{Y}_{7}$ & 0,873 & 0,972 \\
\hline $\mathrm{X}_{1,8}$ & 0,642 & 0,921 & $\mathrm{X}_{2,8}$ & 0,913 & 0,970 & $\mathrm{Y}_{8}$ & 0,914 & 0,970 \\
\hline $\mathrm{X}_{1,9}$ & 0,366 & 0,933 & $\mathrm{X}_{2,9}$ & 0,908 & 0,971 & $\mathrm{Y}_{9}$ & 0,840 & 0,973 \\
\hline $\mathrm{X}_{1,10}$ & 0,619 & 0,921 & $\mathrm{X}_{2,10}$ & 0,916 & 0,970 & $\mathrm{Y}_{10}$ & 0,831 & 0,973 \\
\hline $\mathrm{X}_{1,11}$ & 0,635 & 0,921 & & & & $\mathrm{Y}_{11}$ & 0,886 & 0,971 \\
\hline $\mathrm{X}_{1,12}$ & 0,881 & 0,910 & & & & & & \\
\hline
\end{tabular}

Dari tabel 3 diketahui bahwa hasil dari uji reliabilitas menunjukkan bahwa semua item pertanyaan yang ada dalam instrumen penelitian adalah valid dan reliabel yaitu karena nilainya di atas nilai $\mathrm{r}_{\text {tabel }}$ dan nilai $\alpha$ sehingga dapat digunakan dalam penelitian.

Hasil uji multikolinearitas menunjukkan bahwa tidak ada masalah multikolinearitas yang dapat dilihat dari nilai VIF untuk kedua variable independen kurang dari 10, dan nilai Tolerance lebih dari 0,100. Hasil uji heteroskedastisitas pada grafik Scatterplot, dapat diketahui bahwa titik-titik menyebar dengan pola yang tidak jelas diatas dan dibawah angka 0 pada sumbu Y sehingga dapat disimpulkan bahwa tidak terjadi masalah heterokedastisitas pada model regresi. Hasil uji linearitas Langrange Multiplier menunjukkan bahwa nilai $\mathrm{R}$ square $\left(\mathrm{R}^{2}\right)$ adalah sebesar 0,001 , dengan nilai $\mathrm{c} 2$ hitung sebesar 0,049 lebi kecil dari $\mathrm{c} 2$ tabel $(0,049<62,830)$, maka dapat disimpulkan bahwa model model linier tepat untuk digunakan.

Tabel 4

Hasil Uji t

\begin{tabular}{|c|c|c|c|c|c|c|c|c|}
\hline \multirow{2}{*}{\multicolumn{2}{|c|}{ Model }} & \multicolumn{2}{|c|}{$\begin{array}{l}\text { Unstandardized } \\
\text { Coefficients }\end{array}$} & $\begin{array}{l}\text { Standardized } \\
\text { Coefficients }\end{array}$ & \multirow[t]{2}{*}{$t$} & \multirow[t]{2}{*}{ Sig. } & \multicolumn{2}{|c|}{ Collinearity Statistics } \\
\hline & & B & $\begin{array}{l}\text { Std. } \\
\text { Error }\end{array}$ & Beta & & & Tolerance & VIF \\
\hline \multirow[t]{3}{*}{1} & (Constant) & 8,570 & 2,563 & & 3,344 & 0,002 & & \\
\hline & Mutasi (X1) & $-0,094$ & 0,057 & $-0,091$ & $-1,642$ & 0,107 & 0,997 & 1,003 \\
\hline & $\begin{array}{l}\text { Motivasi } \\
\text { Kerja (X2) }\end{array}$ & 0,977 & 0,059 & 0,918 & 16,554 & 0,000 & 0,997 & 1,003 \\
\hline
\end{tabular}

Berdasarkan perhitungan tersebut diperoleh persamaan regresi linear sebagai berikut: $\mathrm{Y}=8,570$ $-0,094 \mathrm{X}_{1}+0,977 \mathrm{X}_{2}$

Pengujian Koefisien regresi variabel mutasi $\left(\mathrm{X}_{1}\right)$ menunjukkan bahwa diperoleh nilai $-\mathrm{t}$ hitung $>-\mathrm{t}$ table $(-1,642>-2,013)$ atau signifikansi $>0,05(0,107>0,05)$. Artinya adalah variabel $\mathrm{X}_{1}$ secara parsial tidak berpengaruh terhadap $\mathrm{Y}$. Dapat disimpulkan bahwa $\mathrm{H}_{1}$ a : mutasi pegawai secara parsial berpengaruh signifikan terhadap kinerja pegawai, ditolak karena tidak terbukti berdasarkan hasil analisis uji t parsial.

Pengujian Koefisien regresi variabel motivasi $\left(\mathrm{X}_{2}\right)$ menunjukkan bahwa nilai $\mathrm{t}$ hitung $>\mathrm{t}$ tabel 
$(16,554>2,013)$ atau signifikansi $<0,05(0,000<0,05)$ berarti bahwa motivasi kerja secara parsial berpengaruh signifikan terhadap kinerja pegawai. Dapat disimpulkan bahwa $\mathbf{H}_{\mathbf{2}} \mathbf{a}$ : motivasi kerja secara parsial berpengaruh signifikan terhadap kinerja pegawai, diterima karena terbukti berdasarkan hasil analisis uji t parsial.

Tabel 5

Hasil Uji F

ANOVA $^{b}$

\begin{tabular}{|c|c|c|c|c|c|c|}
\hline \multicolumn{2}{|c|}{ Model } & \multirow{2}{*}{$\begin{array}{c}\begin{array}{c}\text { Sum of } \\
\text { Squares }\end{array} \\
3712,916\end{array}$} & $\mathrm{df}$ & $\begin{array}{l}\text { Mean } \\
\text { Square }\end{array}$ & \multirow{2}{*}{$\frac{F}{140,178}$} & \multirow{2}{*}{$\frac{\text { Sig. }}{0,000^{\mathrm{a}}}$} \\
\hline 1 & Regression & & 2 & 1856,458 & & \\
\hline & Residual & 609,206 & 46 & 13,244 & & \\
\hline & Total & 4322,122 & 48 & & & \\
\hline
\end{tabular}

Dari Tabel 4.20 diketahui bahwa variabel $\mathrm{X}_{1}$ dan $\mathrm{X}_{2}$ secara bersama-sama berpengaruh terhadap $\mathrm{Y}$ karena nilai $\mathrm{F}$ hitung $>\mathrm{F}$ tabel $(140,178>3,200)$ atau signifikansi $<0,05(0,000<0,05)$. Dapat disimpulkan bahwa $\mathrm{H}_{3}$ a yaitu mutasi pegawai dan motivasi kerja secara simultan berpengaruh signifikan terhadap kinerja pegawai diterima karena terbukti berdasarkan analisis Uji F.

Tabel 6

Nilai Koefisien Determinasi $\left(\mathrm{R}^{2}\right)$

\begin{tabular}{llrrrr}
\hline Model & R & $\begin{array}{c}\text { R } \\
\text { Square }\end{array}$ & $\begin{array}{c}\text { Adjusted R } \\
\text { Square }\end{array}$ & $\begin{array}{c}\text { Std. Error of } \\
\text { the Estimate }\end{array}$ & $\begin{array}{c}\text { Durbin- } \\
\text { Watson }\end{array}$ \\
\hline 1 & $0,927^{\mathrm{a}}$ & 0,859 & 0,853 & 3,639 & 1.667 \\
\hline
\end{tabular}

Berdasarkan tabel 6 dapat diketahui bahwa variabel $\mathrm{X}_{1}$ dan $\mathrm{X}_{2}$ secara bersama-sama memiliki sumbangan pengaruh terhadap Y sebesar 0,859 atau 85,9\%. Sedangkan sisanya sebesar 14,1\% dipengaruhi oleh faktor lain yang tidak diteliti.

\section{Pembahasan}

Hasibuan (2016) menyatakan salah satu sistem yang digunakan sebagai dasar pelaksanaan mutasi pegawai adalah Sistem Merit. Sistem merit yaitu sistem mutasi pegawai dilakukan secara objektif berdasarkan pertimbangan-pertimbangan yang bersifat ilmiah, serta dengan mempertimbangkan prestasi kerja yang telah dicapai. Sistem Merit ini merupakan sistem mutasi yang paling baik dibandingkan dengan sistem senioritas maupun sistem spoil karena merupakan sistem yang dianggap paling adil dan dapat memacu peningkatan kinerja dan produktivitas pegawai.

Ketentuan mengenai mutasi diatur dalam Peraturan Pemerintah Republik Indonesia Nomor 11 Tahun 2017 tentang Manajemen Pegawai Negeri Sipil. Dalam pasal 162 Peraturan Pemerintah tersebut, disebutkan bahwa:

"Pengembangan karier, pengembangan kompetensi, pola karier, mutasi, dan promosi merupakan manajemen karier PNS yang harus dilakukan dengan menerapkan prinsip Sistem Merit."

Berdasarkan hasil analisis deskriptif data yang telah dilakukan diketahui bahwa mekanisme mutasi yang dilaksanakan di lingkungan Badan Pemeriksa Keuangan belum sepenuhnya berdasarkan merit sistem. Tanggapan dari responden terkait dengan pelaksanaan mutasi menunjukkan bahwa mutasi yang dilaksanakan belum menggunakan pertimbangan-pertimbangan ilmiah dan kinerja yang telah dicapai.

Hamzah dalam Astuti (2017) menyatakan bahwa indikator motivasi kerja dapat dikelompokkan 
menjadi motivasi internal dan motivasi eksternal. Motivasi internal yaitu motivasi yang berasal dari dalam diri seseorang. Motivasi ini tidak dapat diubah oleh orang lain (manajemen maupun organisasi) kecuali atas kemauan orang itu sendiri. Motivasi eksternal yaitu motivasi yang berasal dari luar atau dari lingkungan seseorang. Motivasi ini yang umumnya digunakan oleh manajemen untuk meningkatkan kinerja seseorang. Hasil analisis data yang diperoleh diketahui bahwa motivasi internal dan eksternal yang dimiliki oleh pegawai BPK Perwakilan Maluku Utara adalah tinggi.

Robbins dalam Sari (2015) mengemukakan bahwa kinerja dapat diukur melalui 6 indikator yaitu: komitmen; kemandirian; efektivitas; ketepatan waktu; kuantitas; dan kualitas. Berdasarkan hasil analisis data yang dilakukan dapat diketahui bahwa komitmen, kemandirian, efektivitas, ketepatan waktu, kuantitas, maupun kualitas kerja pegawai BPK Perwakilan Maluku Utara tinggi. Hipotesis pertama dari penelitian ini adalah bahwa mutasi berpengaruh signifikan terhadap kinerja pegawai pada BPK Perwakilan Provinsi Maluku Utara. Pengaruh mutasi terhadap kinerja pegawai dapat diketahui dalam uji hipotesis. Dari hasil pengujian tersebut diketahui bahwa mutasi tidak berpengaruh secara signifikan terhadap kinerja pegawai di BPK Perwakilan Provinsi Maluku Utara.

Teori-teori mutasi yang digunakan dalam penelitian ini yaitu: a) Siagian dalam Dewi (2017) yang menyatakan bahwa mutasi berfungsi untuk memberikan pengalaman baru, memperluas pengetahuan dan keterampilan karyawan, menghindari kejenuhan, untuk mengisi lowongan yang ada, dan meningkatkan motivasi karyawan. b) Hasibuan (2016) yang menyatakan bahwa tujuan pelaksanaan mutasi antara lain adalah untuk meningkatkan produktivitas, menempatkan orang-orang pada posisi yang tepat, meningkatkan pengetahuan pegawai, mendorong perencanaan karier, dan menciptakan keseimbangan struktur organisasi.

Dari teori-teori tersebut dapat dilihat bahwa, tujuan organisasi dalam melaksanakan mutasi adalah untuk meningkatkan produktivitas kinerja. Untuk dapat mencapai tujuan tersebut, mutasi harus dilaksanakan dengan sistem mutasi yang tepat dan terencana. Dapat disimpulkan bahwa sistem mutasi yang tepat akan berpengaruh terhadap meningkatnya kinerja pegawai.

Lebih lanjut menurut Mahmudi dalam Sayd dkk. (2016), faktor-faktor yang dapat mempengaruhi kinerja individu antara lain adalah faktor sistem dan konteks. Sistem yaitu lingkungan kerja yang dibentuk oleh organisasi yang meliputi peraturan dan kebijakan yang membentuk budaya kerja organisasi, termasuk juga di dalamnya adalah sistem mutasi. Sedangkan konteks adalah kondisi lingkungan internal dan eksternal organisasi baik berupa ancaman dan peluang. Dalam penelitian ini, teori-teori tersebut tidak terbukti.

Berdasarkan analisis data lebih lanjut diketahui bahwa terdapat beberapa data jawaban responden yang tidak sesuai dengan teori yang ada yaitu bahwa mutasi berpengaruh positif dan signifikan terhadap kinerja pegawai. Sebagian pegawai dengan rata-rata persepsi mutasi rendah namun memiliki kinerja yang tinggi atau sangat tinggi. Demikian juga sebalikya, beberapa pegawai dengan rata-rata persepsi mutasi tinggi namun memiliki kinerja yang rendah atau sangat rendah. Penelitian lebih lanjut terhadap data responden, diketahui bahwa pegawai-pegawai dengan kinerja tinggi ternyata juga memiliki motivasi yang tinggi meskipun persepsi mutasinya rendah. Dapat dijelaskan bahwa meskipun pegawai memiliki penilaian terhadap mutasi yang rendah namun motivasi internalnya tinggi sehingga kinerjanya juga tinggi. Demikian juga pegawai-pegawai dengan kinerja rendah ternyata juga memiliki motivasi kerja khususnya motivasi internal yang rendah meskipun persepsi mutasinya tinggi. Hal ini mungkin terjadi karena sebagaimana disebutkan sebelumnya bahwa motivasi internal adalah motivasi bawaan yang tidak dapat dipengaruhi oleh lingkungan eksternal termasuk manajemen dan organisasi. Kebijakan mengenai mutasi sebagai salah satu bentuk lingkungan yang dibangun oleh organisasi tidak memiliki pegaruh terhadap motivasi dan kinerja pegawai.

Berdasarkan hasil wawancara secara lebih mendalam dengan Pejabat yang berkaitan dengan Pengelolaan Sumber Daya Manusia, diketahui bahwa banyaknya pegawai dengan usia sangat produktif dan relatif muda mengakibatkan masih tingginya idealisme dan etos kerja yang dimiliki. Perlu 
diketahui pula bahwa BPK memiliki nilai-nilai dasar sebagai idealisme yang harus diterapkan dalam melaksanakan pekerjaan yaitu nilai independensi, integritas, dan profesionalisme. Sehingga meskipun memiliki persepsi mutasi pegawai yang rendah pegawai-pegawai tetap harus bekerja sesuai tuntutan profesionalisme kerja untuk menghasilkan kinerja yang baik.

Teori Maslow dalam Purwanto (2017) menyatakan bahwa kebutuhan manusia terdiri dari 5 hierarki kebutuhan yaitu kebutuhan fisiologis, kebutuhan akan keamanan, kebutuhan sosial, kebutuhan akan penghargaan, dan kebutuhan aktualisasi diri. Teori Herzberg dalam Purwanto (2017) menyatakan bahwa motivasi seseorang dipengaruhi oleh 2 kondisi yaitu kondisi yang mendorong motivasi dan kondisi yang menghambat motivasi. Teori Alderfer dalam Dimyati (2018) menyatakan bahwa motivasi timbul dari 3 kelompok kebutuhan yaitu eksistensi, keterkaitan, dan pertumbuhan.

Dari berbagai teori tersebut dapat disimpulkan bahwa manusia/pegawai terdorong untuk melakukan upaya semaksimal mungkin dengan tujuan untuk memenuhi kebutuhannya. Upaya yang maksimal inilah yang kemudian akan berakibat pada peningkatan kinerja individu. Dapat dikatakan bahwa motivasi kerja sangat berpengaruh terhadap kinerja individu. Dalam penelitian ini, teori tersebut terbukti berdasarkan hasil analisis regresi yang menunjukkan bahwa terdapat pangaruh signifikan antara motivasi kerja terhadap kinerja pegawai pada BPK Perwakilan Provinsi Maluku Utara.

Dari hasil pengujian diketahui bahwa mutasi dan motivasi secara simultan berpengaruh secara signifikan terhadap kinerja pegawai di BPK Perwakilan Provinsi Maluku Utara. Artinya jika sistem mutasi baik dan motivasi pegawai semakin tinggi, maka kinerjanya akan semakin baik dan sebaliknya jika sistem mutasi rendah dan motivasi pegawai rendah maka kinerjanya akan semakin menurun.

Meskipun dari hasil penelitian variabel mutasi pegawai tidak berpengaruh secara signifikan terhadap kinerja, namun secara bersama-sama variabel mutasi dan motivasi kerja berpengaruh secara signifikan terhadap kinerja pegawai. Hal ini menunjukkan bahwa variabel motivasi kerja memiliki pengaruh yang sangat besar terhadap kinerja pegawai.

\section{PENUTUP}

\section{Kesimpulan}

Berdasarkan hasil pengujian mengenai analisis pengaruh mutasi dan motivasi kerja terhadap kinerja pegawai pada BPK Perwakilan Provinsi Maluku Utara, dapat disimpulkan hal-hal sebagai berikut:

1. Mutasi yang dilaksanakan di lingkungan Badan Pemeriksa Keuangan belum sepenuhnya berdasarkan merit sistem. Persepsi pegawai atas mutasi menunjukkan bahwa mutasi yang dilaksanakan belum menggunakan pertimbangan-pertimbangan ilmiah dan tidak berdasarkan kinerja yang telah dicapai. Pegawai pada BPK Perwakilan Provinsi Maluku Utara merasa kebijakan mutasi pegawai di lingkungan Badan Pemeriksa Keuangan belum ditetapkan dengan jelas dan kurangnya transparansi serta konsistensi menimbulkan kesan bahwa mutasi yang ada belum dilaksanakan secara objektif dan ilmiah.

2. Motivasi yang dimiliki oleh pegawai BPK Perwakilan Maluku Utara adalah tinggi. Dapat disimpulkan bahwa BPK Maluku Utara mampu untuk meningkatkan motivasi pegawai melalui faktor-faktor eksternal seperti insentif, lingkungan kerja yang harmonis, dan penghargaan yang diberikan.

3. Kinerja pegawai pada BPK Perwakilan Provinsi Maluku Utara tinggi yang ditunjukkan dengan tingginya komitmen, kemandirian, efektivitas, ketepatan waktu, kuantitas, maupun kualitas kerja pegawai BPK Perwakilan Maluku Utara.

4. Mutasi terbukti tidak berpengaruh secara signifikan terhadap kinerja pegawai pada BPK Perwakilan Provinsi Maluku Utara. Hal ini disebabkan karena adanya faktor-faktor bawaan (internal) yang berpengaruh pada kinerja maupun motivasi. 
5. Motivasi kerja berpengaruh secara positif dan signifikan terhadap kinerja pegawai pada BPK Perwakilan Provinsi Maluku Utara. Jika motivasi seorang pegawai semakin tinggi, maka kinerjanya akan semakin baik dan sebaliknya jika motivasi seorang pegawai rendah maka kinerjanya akan semakin menurun.

6. Mutasi dan motivasi kerja secara simultan berpengaruh secara signifikan terhadap kinerja pegawai pada BPK Perwakilan Provinsi Maluku Utara. jika sistem mutasi baik dan motivasi pegawai semakin tinggi, maka kinerjanya akan semakin baik dan sebaliknya jika sistem mutasi rendah dan motivasi pegawai rendah maka kinerjanya akan semakin menurun.

Saran

Saran yang dapat diberikan berdasarkan penelitian ini adalah:

1. Bagi BPK RI agar lebih meningkatkan kualitas mutasi pegawai, khususnya dalam hal implementasi kebijakan sebagaimana ditetapkan dalam Peraturan Pemerintah Nomor 11 Tahun 2017 tentang Manajemen Pegawai Negeri Sipil. Selain itu, BPK RI agar memperbaiki regulasi/standar mengenai mekanisme mutasi pegawai di lingkungan internal BPK berdasarkan merit sistem dan kemudian melakukan sosialisasi secara kontinyu mengenai mekanisme tersebut.

2. Bagi BPK Perwakilan Provinsi Maluku Utara agar selalu memantau dan meningkatkan motivasi kerja yang dimiliki oleh pegawainya. Peningkatan motivasi pegawai erat kaitannya dengan pemenuhan kebutuhan pegawai. Beberapa upaya yang dapat dilakukan oleh organisasi untuk meningkatkan motivasi pegawai antara lain adalah pemberian insentif, menciptakan lingkungan kerja yang nyaman, menciptakan hubungan yang harmonis antar pegawai, mendorong kerja sama tim yang baik, maupun memberikan penghargaan terhadap prestasi yang dicapai oleh karyawan.

3. Bagi BPK Perwakilan Provinsi Maluku Utara agar selalu mempertahankan dan meningkatkan kinerja yang dimiliki oleh pegawainya. Untuk dapat meningkatkan kinerja pegawai beberapa hal yang dapat dilakukan oleh organisasi antara lain adalah peningkatan kompetensi pegawai melalui pendidikan dan pelatihan, meningkatkan kepuasan kerja karyawan, atau dengan menciptakan iklim kerja yang kompetitif dengan pemberian reward and punishment.

4. Bagi penelitian selanjutnya dapat memperdalam penelitian mengenai variabel mutasi pegawai mengingat dalam penelitian ini variabel mutasi pegawai tidak terbukti berpengaruh signifikan terhadap kinerja pegawai.

5. Bagi penelitian selanjutnya dapat memperdalam penelitian terhadap variabel-variabel yang berpengaruh terhadap motivasi kerja karena dalam penelitian ini variabel motivasi kerja memiliki pengaruh yang sangat signifikan terhadap kinerja pegawai.

6. Bagi peneliti selanjutnya dapat melakukan penelitian terhadap variabel lain yang berpengaruh terhadap kinerja pegawai selain mengingat bahwa masih terdapat 14,1\% (100\%-85,9\%) variabel lain yang berpengaruh terhadap kinerja pegawai.

\section{REFERENSI}

Astuti. (2017). Analisis Motivasi Kerja Karyawan Dalam Upaya Meningkatkan Produktivitas Kerja Karyawan Studi Kasus Bagian Assembling Perusahaan Metal Button. Bandung: Universitas Pasundan Bandung.

Budiman, Arif (2018). Employee Transfer: a Review of Recent Literature. Journal of Public Administration Studies. JPAS Vol. 3 No. 1, pp 33-36, 2018. ISSN: 2548-902X. Diunduh 24 April 2019, dari situs World Wide Web: https://jpas.ub.ac.id

Dewi, J.P. (2017). Pengaruh Mutasi dan Motivasi terhadap Kinerja Karyawan PT. Buana Samudra Lestari. Bekasi: Sekolah Tinggi Ekonomi Pelita Bangsa.

Dimyati, A. (2018). Pengaruh Mutasi terhadap Motivasi Pegawai pada Dinas Perumahan Kawasan Pemukiman dan Pengelolaan Sumber Daya Air Provinsi Lampung (Penelitian). Diunduh 19 April 2019 dari situs World Wide Web: http://docplayer.info 
Hasibuan, M.S.P. (2016) Manajemen Sumber Daya Manusia. Edisi Revisi. Jakarta: Bumi Aksara. Mangkunegara, A.P. (2017). Manajemen Sumber Daya Manusia Perusahaan. Cetakan Keempat Belas Bandung: PT. Remaja Rosda Karya.

Panggabean, M. S. (2016). Manajemen Sumber Daya Manusia. Edisi 2. Cetakan Ketiga. Tangerang: Universitas Terbuka.

Prasetya, Arik (2018). Analysis of Factors that Influence Employee Performance (Study on Permanent Employees in Operationel Section of PT WIMCycle Indonesia-Surabaya). Jurnal Profit Volume 12 No. 1. 2018. Diunduh 24 April 2019, dari situs World Wide Web: https://profit.ub.ac.id

Purwanto, Agus J., Elu, Wilfridus B. (2017). Inovasi dan Perubahan Organisasi. Edisi Kedua. Cetakan Pertama. Tangerang Selatan: Universitas Terbuka.

Putri, G.F. (2016). Pengaruh Mutasi Kerja terhadap Kinerja Karyawan Operasional di Vio Cihampelas Hotel Bandung. Bandung: Sekolah Tinggi Pariwisata Bandung. Diunduh 3 September 2019 dari situs World Wide Web: http://repository.stp-bandung.ac.id

Sari, D. (2015). Jurnal Pengaruh Kepuasan Kerja dan Komitmen Organisasi terhadap Kinerja Karyawan pada PT. PUSKOPKAR Riau Pekanbaru. JOM FEKON Vol. No. Februari 2015.

Sayd. G.A., dkk. (2016). Jurnal Faktor-Faktor yang Mempengaruhi Kualitas Kinerja Kantor Pertanahan Rote Ndao. Jurnal Ilmu Sosial dan Politik Volume 19, Nomor 3, Maret 2016 (264-274). ISSN $1410-4946$.

Sutrisno, Edy. (2016). Manajemen Sumber Daya Manusia. Cetakan Kedelapan. Jakarta: Kencana Prenada Media Group.

Wutsqo, W. U. (2017). Pengaruh Mutasi dan Pemberian Insentif terhadap Kinerja Pegawai (Studi Kasus pada Kantor Pelayanan Pajak Penanaman Modal Asing Lima Jakarta). Yogyakarta: Universitas Negeri Yogyakarta. Diunduh 3 September 2019 dari situs World Wide Web: https:/eprints.uny.ac.id

Peraturan Pemerintah Nomor 11 Tahun 2017 tentang Manajemen Pegawai Negeri Sipil. 